\title{
Radionuclide migration and organoleptic characteristics of beef in the adjacent areas to the former Semipalatinsk nuclear test site
}

\author{
Assel Zhexenayeva - Sergazy Duyssembaev • Gulnara Saparova - Kabysheva Zhanar • Serikova Aynur
}

A Zhexenayeva (Corresponding author) - S Duyssembaev • email: asel1980@inbox.ru

G Saparova - K Zhanar - SAynur

Department of Veterinary, Shakarim State University of Semey, 159 Shugaev str., Semey, 071400, Kazakhstan.

Received: February 03, 2020 • Accepted: March 17, 2020 • Published Online: April 08, 2020

\begin{abstract}
This article presents the results of the migration of radionuclides along the soil-water-feed-animal livestock chain in the adjacent territories of the former Semipalatinsk nuclear test site (SNTS). To analyze the radio ecological situation in the territory adjacent to the SNTS, 6 stationary control points were created, from which samples of soil, water, vegetation, and animal products were taken. The radiometric method was used to determine the radioactive background of the studied areas. Gamma-, alpha-spectrometry methods were used to study the content of radionuclides. The radionuclide transfer along the soil-water-feed-animal livestock chain was determined by a calculation method and also veterinary and sanitary examination of the beef selected from these items. The research results show that in all the test points under study the EDR values, the beta-particles flux density is below the limit of permissible values. The samples detected radionuclides as $\mathrm{Am}-241, \mathrm{Cs}-137$ and $\mathrm{Pu}-239 / 240$ not exceeding the standards established by the Hygienic standards of the Republic of Kazakhstan. The chain of radionuclides was transferred to animal products. The organoleptic assessment of the quality of cattle meat showed that inconsistencies are observed: a slight increase in lymph nodes, muddy broth, and surface moisture of muscle.
\end{abstract}

Keywords: beta particle flux density, dose rate, emergency zone of radiation risk, organoleptic, radionuclide migration and transition

\section{Introduction}

One of the most important problems currently facing agricultural radioecology is the study of patterns of radionuclide migration in the trophic chain of cattle in the territory that has been contaminated as a result of nuclear tests of the former SNTS (Kudryavtsev 1991). The SNTS has left a huge mark on the history of the nuclear race during the Cold War period. On August 29, 1949, the Soviet Union produced the first nuclear explosion on the territory of Kazakhstan.
From this day began the 40-year history of the SNTS. 456 nuclear explosions, among which 116 ground and 340 underground explosions, led to radioactive contamination not only of the landfill but also of the adjacent territories where people live. The leakage of radioactive waste, public discontent - all this led to the anti-nuclear movement "Nevada-Semipalatinsk" with O. Suleimenov at the head. Having gained independence, on August 29, 1991, the President of the Republic of Kazakhstan issued a decree on the closure of the SNTS. From that moment on, the Republic of Kazakhstan embarked on the path of non-proliferation and the complete destruction of nuclear weapons and an arsenal (Karabalin et al 2001; Panitskiy et al 2019; Semenova et al 2019).

Contaminated areas are those in which the effective equivalent radiation dose for the population exceeds $0.1 \mathrm{rem}$ over the entire test period. Depending on the size of the effective equivalent dose, the contaminated areas are divided into four zones: 1) emergency radiation risk zone is the part of the territory that has been subjected to radiation contamination, with a population exposure dose exceeding 100 rem during the entire test period that is in the maximum seismic impact band; 2) zone of maximum radiation risk - the part of the territory that has been subjected to radiation pollution, with a dose to the population of 35 to 100 rem for the entire test period; 3) zone of increased radiation risk - the part of the territory that has been subjected to radiation pollution, with a dose of exposure to the population from 7 to 35 rem for the entire test period; 4) zone of minimum radiation risk - the part of the territory that has been subjected to radiation pollution, with a dose of exposure to the population from 0.1 to $7 \mathrm{rem}$ for the entire test period (Law of the Republic of Kazakhstan N 1787-XII 1992).

The approval of the SNTS border and the return of part of the land to agricultural use is one of the successful steps taken by the National Nuclear Center of the Republic of Kazakhstan. Nevertheless, many scientists and residents of 
settlements close to the SNTS consider it hasty to return lands to public use, due to the danger of the migration of dangerous radionuclides to the biological chain of the environment. In this regard, there is a need to monitor the territories of the SNTS and to identify radiation-hazardous sites (Gorlachev et al 2019; Rikhvanov 2009).

The complication of the radiation situation on the territory of the East Kazakhstan, Pavlodar and Karaganda regions of the Republic of Kazakhstan is due to the activities of the former Semipalatinsk nuclear test site, mining, and processing of minerals with a high content of radioactive elements, natural radioactive anomalies in places where people live and in groundwater used for drinking water supply. In addition, there are sites where radioactive waste is located (Lukashenko 2008).

According to scientists from around the world, the fallout of radioactive substances has become global in nature and caused radioactive contamination of the biosphere. Radionuclides falling to the surface of the earth were found in the atmosphere, soil, water, plants, animals and humans, creating additional irradiation of living organisms. Food contamination causes the entry of radionuclides into the human body and its exposure. Therefore, the flow of radioactive substances into the external environment has caused and continues to cause well-founded anxiety and concern of the world community (Amirbekov et al 2013; Apsalikov et al 2019; Balmukhanov et al 2006; Spiridonov et al 2008).

The intake of radionuclides into the organism of farm animals and the products obtained from them should be assessed in conjunction with their source of nutrition, plants, and the level of accumulation of radionuclides in plants depends on the composition of the soil and water atmosphere. The main source of radioactive substances in animals is feed, to lesser extent water and air (Gudkov 1991). Radioactive substances enter the body of farm animals through the gastrointestinal tract in the composition of the feed, and, with grazing, besides, along with turf and soil particles. The increased interest of researchers to the migration of radionuclides in the feed-milk link is caused by the fact that milk and dairy products cause $25-100 \%$ of radioactive substances in the human body (Radiological conditions at the Semipalatinsk test site, Kazakhstan 1998). Receipts of nuclear fission products through the gastrointestinal tract and neutron activation of agricultural animals, the transfer of radionuclides from the diet to meat is due to the physicochemical properties of the radionuclides, the type of animals and their age. Once inside the body, radioactive atoms emit radiation that permits living cells or at least weakens the body's defensive response (Semenova 2018).

Under the conditions of continuous chronic intake of Sr-90 and Cs-137 with food, the equilibrium state of radionuclides in organs and tissues $(\mathrm{Bk} / \mathrm{kg})$ is reached approximately 30-40 days after the start of feeding contaminated feed. In the future, in growing animals, the concentration of radionuclides in the muscle tissue and internal organs remains almost unchanged. Therefore, obtaining predicted values for the transfer of radionuclides into livestock products is of great practical importance for the assessment of dose loads on the population living in the adjacent territories to the former SNTS (Larionova 2011).

The aim of this research is to observe the migration of radionuclides from the soil-water-feed-animals livestock products in order to assess and predict their biological effects on farm animals, levels of radionuclide contamination and safety of products received from them in the adjacent areas of the former SNTS. The conducted studies will help to draw up a detailed map of contamination by radionuclides of the investigated territory based on radiological analysis of the surface layers of the soil and water sources, to study the degree of accumulation of radioactive elements in the soil, vegetation, drinking water, and food products of the studied settlements.

\section{Materials and Methods}

To achieve the goal of this research, we selected nearby settlements to the former SNTS from an emergency radiation risk zone: the villages of Boden, Sarapan, Sarzhal, Dolon, Mostik, and the wintering Zhanan. To analyze the radioecological situation in the territory adjacent to the SNTS, six stationary control points were created, from which samples of soil, water, vegetation, and animal products were taken.

Before sampling at the control points, radiometric monitoring was carried out. To conduct radiometric monitoring in the studied areas, instruments and measuring devices were used, which annually pass the state calibration. Preparation for instrumental measurements were carried out in accordance with the instructions for use of these devices. The dose rate of gamma radiation, the flux density of beta particles was determined according to State Standard (SS) 26307-84, 26306-84. Next, we took samples of soil, plants, water and animal products (milk and meat) in the studied settlements. Sampling was carried out according to updated interstate standards and standards of the Republic of Kazakhstan: SS 17.4.3.01-83; SS 27262-87; SS 51592-2003; Sampling of meat and milk and dairy products was carried out according to SS RK 1623-2007.

Sample preparation and measurements for radionuclide composition were carried out according to the following methods: the method for determining the content of artificial $\mathrm{Pu}-239,240$ radionuclides, Sr-90 in environmental objects (soils, soils, bottom sediments, and plants); methods for determining the content of artificial radionuclides of $\mathrm{Pu}-239$, 240, Sr-90 and Cs-137 in natural waters by the method of concentration radionuclide activity in bulk samples. The method of measurement on a gamma spectrometer ST RK 
1623-2007 Radiation monitoring. The food products were measurements were carried out on alpha and gamma spectrometers of the company "CANBERRA".

Selected samples were delivered to the testing regional laboratory of engineering profile "Scientific Center of Radioecological Research" Shakarim State University. To determine Cs-137 and Am-241 samples of the soil, the plants were dried to an air-dry state, with periodic mixing. Next, samples of the soil were ground with a mortar and pestle and sieved through sieves with a diameter of $2 \mathrm{~mm}$, and the samples of plants were ground in a blender. The sample was placed in the measuring capacitance (the weight of the sample depending on the volume of the vessel being measured) and the radionuclide composition was measured on a CANBERRA gamma spectrometer with an electro cooled detector. Samples of water were filtered through a white ribbon filter, then preserved with nitric acid at the rate of $3 \mathrm{ml}$ per 11 of the sample $(\mathrm{pH}<1)$. The $\mathrm{pH}$ was controlled on indicator paper. Samples of meat were cut into small pieces and crushed using an electric meat grinder and placed in a vessel Marinelli, milk samples were poured from bottles into vessels Marinelli. Next, the samples were measured on a gamma spectrometer.

In order to determine the Pu-239, 240 in samples, a phased radiochemical analysis was carried out: Stage 1 sample preparation (drying, ashing); Stage 2 - leaching of samples with acids; Stage 3 - sorption and desorption on chromatographic columns; Stage 4 - precipitation of plutonium. After radiochemical analysis, samples were measured on an alpha spectrometer.

By calculation, the $\mathrm{CP}$ of radionuclides $(\mathrm{Bk} / \mathrm{kg})$ was determined from soil to plants, then from plants to meat and milk of animals using the following formula:

$$
C_{t}=\frac{A_{\text {plants }}}{A_{\text {soil }}}
$$

where: $\mathrm{C}_{\mathrm{t}}$ is the transition coefficient; $A_{\text {plants }}$ is the concentration of radionuclides in the plant $(\mathrm{Bk} / \mathrm{kg}) ; A_{\text {soil }}$ is the concentration of radionuclides in the soil $(\mathrm{Bk} / \mathrm{kg})$.

Veterinary and sanitary examination of beef performed in the slaughterhouses, the above settlements, and the department "Veterinary Sanitation" Semey State Shakarim University.

Sampling and organoleptic quality assessment and determination of the degree of freshness of meat were carried out according to SS 7269-79. From each carcass to be examined for freshness, samples were taken weighing about $200 \mathrm{~g}$ each, in a single piece, if possible, of a cubic form. Samples were taken from the notch against the 4th and 5th cervical vertebrae. The samples also included bone marrow bones, fat, and tendons.

Statistical analysis was performed using Statistica 12.0 program (STATISTICA 2014; Stat Soft Inc., Tulsa, OK,
USA). The differences between samples were evaluated using the ANOVA method. The differences were considered to be statistically significant at $P \leq 0.05$.

\section{Results and Discussion}

The radiation examination of a day surface was conducted in the Searching mode. Places with the maximal values of capacities of air dose (further - EDR) were allocated as sampling points of the soil and plants for a research for a content of natural and simulated radionuclides. Results of radiation inspection of a day surface are presented in Figures 1 and 2. As can be seen from Fig. 1, the level of EDR in the area of emergency radiation risk ranged from $0.22 \mu \mathrm{Sv} / \mathrm{h}$ to $0.35 \mu \mathrm{Sv} / \mathrm{h}$. The highest rates in the village of Bodene are 0.32 $\mu \mathrm{Sv} / \mathrm{h}$ and in the wintertime Zhanan $0.35 \mu \mathrm{Sv} / \mathrm{h}$. In the zone of emergency radiation risk, measured values of the betaparticles flux density in all the research sites were $<10$ parts $/ \min \times \mathrm{cm}^{2}$, and beta-particles flux density from 6.5 parts $/ \mathrm{min} \times \mathrm{cm}^{2}$ to 9.1 parts $/ \mathrm{min} \times \mathrm{cm}^{2}$.

The results of alpha- and gamma-spectrometry analyzes of environmental samples and animal products are given in tables 1-5. According to Table 1, in the emergency zone of radiation risk, the level of specific activity of Am-241 from $9.0 \pm 0.2 \mathrm{Bk} / \mathrm{kg}$ to $91.5 \pm 1.8 \mathrm{Bk} / \mathrm{kg}$, Cs-137 from $35.5 \pm$ $1 \mathrm{Bk} / \mathrm{kg}$ to $3658.6 \pm 22.5 \mathrm{Bk} / \mathrm{kg}, \mathrm{Pu}-239 / 240$ from $0.2 \pm 0.1$ $\mathrm{Bk} / \mathrm{kg}$ to $11.4 \pm 0.3 \mathrm{Bk} / \mathrm{kg}$.

The results of the content of radionuclides in the samples of plants are shown in Table 2. It can be seen that the specific activity of radionuclides in the emergency zone of radiation risk is $\mathrm{Am}-241$ from $1.5 \pm 0.2 \mathrm{Bk} / \mathrm{kg}$ to $25.8 \pm 0.2 \mathrm{Bk} / \mathrm{kg}, \quad \mathrm{Cs}-137$ from $2.8 \pm 0.4 \mathrm{Bk} / \mathrm{kg}$ to $1150.3 \pm 10 \mathrm{Bk} / \mathrm{kg}, \quad \mathrm{Pu}-239 / 240$ from $0.5 \mathrm{Bk} / \mathrm{kg}$ to $2.2 \pm 0.2 \mathrm{Bk} / \mathrm{kg}$. These data indicate that part of the radionuclides is transferred from the soil to the plants.

The volumetric activity of radionuclides in water samples in the zone of emergency radiation risk amounted to Am-241 from 0.05 to $0.15 \mathrm{Bk} / 1$, Cs-137 from 0.5 to $2.5 \mathrm{Bk} / \mathrm{l}$, $\mathrm{Pu}-239 / 240$ from 0.004 to $0.05 \mathrm{Bk} / \mathrm{l}$.

The research results show that radionuclides are present in water samples (Table 3) in quantities that are significantly lower than intervention levels (Health standards no. $201, \mathrm{Cs}^{137}-11 \mathrm{Bk} / \mathrm{kg}, \mathrm{Am}^{241}-0.69 \mathrm{Bk} / \mathrm{kg}, \mathrm{Pu}^{239 / 240}-$ $0.55 \mathrm{Bk} / \mathrm{l})$. However, their very presence in these regions requires additional research.

Plants growing in the fields and meadows are sources of radioactive substances in the body of farm animals and contamination of the products obtained from them (meat, milk). Beef and dairy cattle per day eat grass from a very large area - up to $160 \mathrm{~m}^{2}$ (per cow), and therefore, radionuclides enter the body of animals intensively. With milk of cows, up to $1 \%$ of cesium and strontium are excreted in the body in their daily diet. 


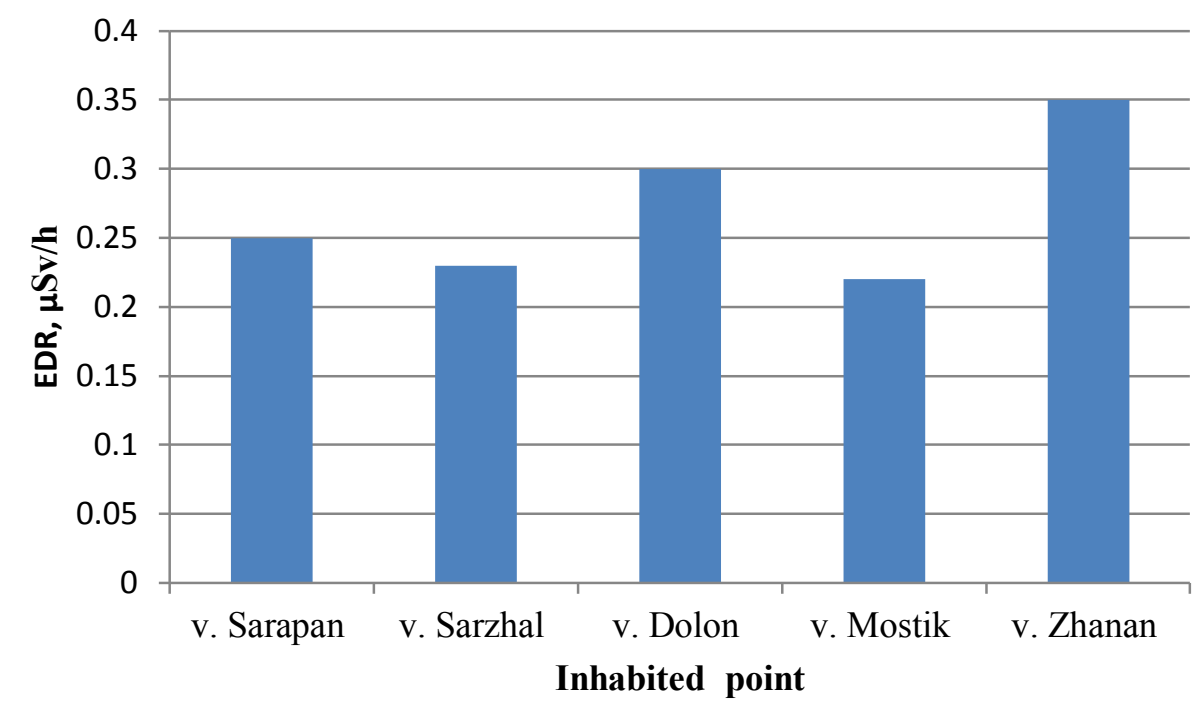

Figure 1 EDR values of the day surface of the studied points.

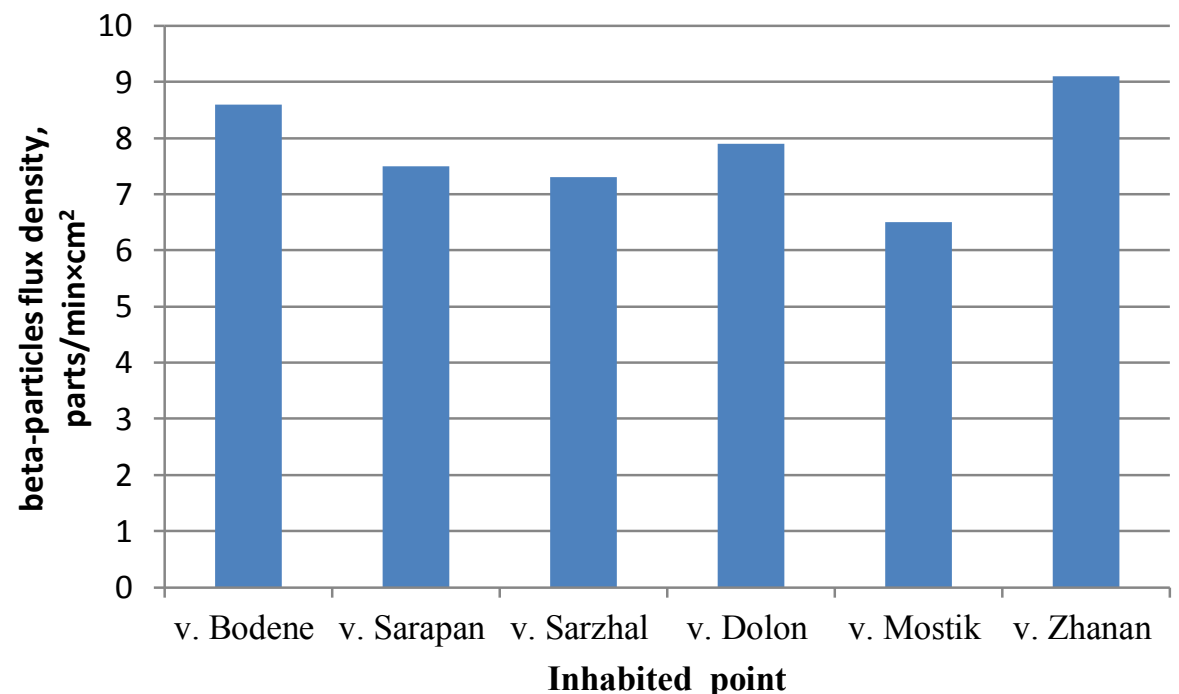

Figure 2 Values of flux density of beta particles of the surface of the points studied.

Table 1 The maintenance of radionuclides in soils.

\begin{tabular}{lccc}
\hline Inhabited point & \multicolumn{3}{c}{ Specific activity of radionuclides, Bq/kg } \\
\cline { 2 - 4 } & Am-241 & Cs-137 & Pu-239/240 \\
\hline v. Bodene & $18.6 \pm 0.5$ & $1322.2 \pm 5.3$ & $2.2 \pm 0.2$ \\
v. Sarapan & $9.0 \pm 0.2$ & $62.2 \pm 5.2$ & $1.4 \pm 0.2$ \\
v. Sarzhal & $15.3 \pm 0.5$ & $35.5 \pm 1$ & $0.5 \pm 0.2$ \\
v. Dolon & $79 \pm 1$ & $94 \pm 0.3$ & $1.8 \pm 0.3$ \\
v. Mostik & $22 \pm 1.2$ & $42 \pm 0.5$ & $0.2 \pm 0.1$ \\
v. Zhanan wintering & $91.5 \pm 1.8$ & $3658.6 \pm 22.5$ & $11.4 \pm 0.3$ \\
\hline
\end{tabular}


Table 2 The maintenance of radionuclides in tests of plants.

\begin{tabular}{lccc}
\hline Inhabited point & \multicolumn{3}{c}{ Specific activity of radionuclides, Bk/kg } \\
\cline { 2 - 4 } & Am-241 & Cs-137 & Pu-239/240 \\
\hline v. Bodene & $1.5 \pm 0.2$ & $58 \pm 0.5$ & $0.7 \pm 0.1$ \\
v. Sarapan & $2.4 \pm 0.4$ & $29 \pm 0.3$ & $0.5 \pm 0.1$ \\
v. Sarzhal & $1.5 \pm 0.3$ & $2.8 \pm 0.4$ & $<0.7$ \\
v. Dolon & $15.2 \pm 0.5$ & $58 \pm 0.5$ & $<0.5$ \\
v. Mostik & $3.5 \pm 0.3$ & $19.7 \pm 0.5$ & $<0.5$ \\
v. Zhanan & $25.8 \pm 0.2$ & $1150.3 \pm 10$ & $2.2 \pm 0.2$ \\
\hline
\end{tabular}

With dairy foods, radioactive elements enter the human body and cause internal irradiation of various organs and tissues, which leads to an increase in the possibility of various diseases. Table 4 shows the radionuclide content in milk samples obtained from cows, contained in settlements, belonging to the zone of emergency radiation risk.

The radionuclides in the examined milk samples are contained but do not exceed permissible levels. According to the results of research in the area of emergency radiation risk, Am-241 ranged Am-241 from 0,5 to 2,3 $\pm 0.2 \mathrm{Bk} / \mathrm{l}, \mathrm{Cs}-137$ from $3.2 \pm 0.2 \mathrm{Bk} / \mathrm{l}$ to $12.3 \pm 0.3 \mathrm{Bk} / \mathrm{l}, \mathrm{Pu}-239 / 240$ from 0.001 to $0.062 \pm 0.01 \mathrm{Bk} / 1$.

According to Table 5, it can be seen that the presented livestock products contain an insignificant number of radionuclides. In samples of beef from the emergency radiation risk zone, Am-241 from 0.2 to $0.51 \pm 0.01 \mathrm{Bk} / \mathrm{kg}$, Cs-137 from 1 to $6.5 \pm 0.5 \mathrm{Bk} / \mathrm{kg}, \mathrm{Pu}-239 / 240$ from 0.02 to $0.08 \mathrm{Bk} / \mathrm{kg}$.

The levels and parameters of the transition of cesium, americium and plutonium radionuclides from soil to plants have been studied. To estimate the parameters of the transfer of radionuclides from soil to plants, Kp was calculated using formula 1, the value of which for cesium, americium, and plutonium in cases of absence of quantitative values of specific activity in samples of plants has been estimated. Morphological features and properties of the soil correspond to the main characteristics of the types. Soils undergo a gradual drying as a result of lowering groundwater, humus content decreases on the surface of the soil a desert crust appears.

The study areas have zonal chestnut, with subtypes of chestnut and light chestnut, underdeveloped soils and undeveloped. Light loamy and medium loamy varieties prevail in terms of mechanical composition, the $\mathrm{pH}$ from the surface is neutral, and below it is alkaline and alkaline. According to the content of organic matter, the soil of the studied areas is average humus $(2-3 \%)$ on average. The content of water-soluble and exchangeable forms of finding radionuclides in the absolute majority of cases are below the detection limit (Dyussembaev et al 2013).

Table 3 The maintenance of radionuclides in water tests.

\begin{tabular}{lccc}
\hline Inhabited point & \multicolumn{3}{c}{ Volume activity of radionuclides, Bk/1 } \\
\cline { 2 - 4 } & Am-241 & Cs-137 & Pu-239/240 \\
\hline v. Bodene & $0.08 \pm 0.02$ & $2.2 \pm 0.1$ & $<0.01$ \\
v. Sarapan & $0.07 \pm 0.01$ & $1.5 \pm 0.4$ & $<0.007$ \\
v. Sarzhal & $0.15 \pm 0.03$ & $1.1 \pm 0.1$ & $<0.005$ \\
v. Dolon & $0.052 \pm 0.01$ & $1.2 \pm 0.2$ & $<0.008$ \\
v. Mostik & $0.05 \pm 0.01$ & $<0.5$ & $<0.004$ \\
v. Zhanan & $0.1 \pm 0.01$ & $2.5 \pm 0.1$ & $<0.05$ \\
\hline
\end{tabular}

Consumption of contaminated feeds is assumed as the main source of entry of nuclear fission products into animals (Larionova et al 2011). Analysis of the data showed that the maximum value of the Am-241 transition coefficient from soil to plants was found in the winter of Zhanan and in the village of Scarapan - 0.27 and 0.28; minimum in Bodene - 0.08. Accordingly, according to Cs-137 in the village of Dolon, the maximum is 0.62 ; minimum in Bodene -0.04 and in $\mathrm{Pu}-$
239/240 maximum in Sarzhal - 1.4; the minimum in wintering Zhanan -0.19 . The release of radionuclides from the soil into plants depends on the type and mineral composition of the soil.

For all studied in plant samples (feather grass - Stipa capillata, fescue - Festuca valesiaca, and wormwood Aztemisia sublessingana) it was established that they accumulate $\mathrm{Pu}, \mathrm{Cs}$, and $\mathrm{Am}$. All the data obtained features of 
the accumulation of radionuclides are heterogeneous for agricultural plants. The accumulation of radioactive substances in plants is associated with changes in physiological processes.

In the feed-milk link, the radionuclide transfer coefficients are the maximum value for Am-241 in Sarzhal 0.47, the minimum value in Dolon - 0.04. According to Cs137 maximum in Sarzhal - 1.71, the minimum in wintering
Zhanan - 0.03; Pu-239/240, respectively, in Boden -0.08, and in the village of Dolony -0.01 .

In the feed-meat link, the radionuclide transfer coefficients are the maximum value for Am-241 in the village of Sarzhal - 0.3; the minimum value in the wintering Zhanan - 0.01. According to Cs-137, the maximum in Sarzhal is 1.3; the minimum in wintering Zhanan - 0.005; Pu-239/240, respectively, in Sarapan - 0.148; and in wintering Zhanan 0.036 .

Table 4 The maintenance of radionuclides in tests of milk.

\begin{tabular}{lccc}
\hline Inhabited point & \multicolumn{3}{c}{ Volume activity of radionuclides, Bk/l } \\
\cline { 2 - 4 } & Am-241 & Cs-137 & Pu-239/240 \\
\hline v. Bodene & $<0.5$ & $7.7 \pm 0.2$ & $0.056 \pm 0.01$ \\
v. Sarapan & $<0.5$ & $8.2 \pm 0.1$ & $0.034 \pm 0.01$ \\
v. Sarzhal & $0.7 \pm 0.1$ & $4.8 \pm 0.6$ & $<0.012$ \\
v. Dolon & $0.6 \pm 0.1$ & $9.3 \pm 0.2$ & $<0.005$ \\
v. Mostik & $<0.5$ & $3.2 \pm 0.2$ & $<0.001$ \\
v. Zhanan & $2.3 \pm 0.2$ & $12.3 \pm 0.3$ & $0.062 \pm 0.01$ \\
\hline
\end{tabular}

According to organoleptic analyzes, carcasses obtained from the Dolon and Boden settlements are described below.

The degree of bleeding: good, there is no blood in the blood vessels, the cut surface is dry, there is a small amount of meat juice. The condition of the site of the cut: Slaughter was carried out in an open way. The location of the incision is uneven, soaked in blood. Determination of hypostases: there are no hypostases in the lower and upper parts of the carcass, that is, there are no blue-red areas soaked in blood. Definition of fatness carcasses: no signs of exhaustion, emaciation were noted, and no signs of dystrophic and degenerative changes in the muscles were found. State of lymph nodes: parotid lymph node (Lymphonodus parotideus) $5-9 \mathrm{~cm}$ long. Submandibular lymph node (Lymphonodus submaxillaris) 3.5 - $5.0 \mathrm{~cm}$ long. Occipital lymph node (Lymphonodus retro pharyngeus medialis) $3.5-5.5 \mathrm{~cm}$ long. Lymphonodus retro pharyngeus lateralis, $4.5-5.5 \mathrm{~cm}$ long. Wing lymph node, Lymphonodus pterygoideus, $0.75-1.0 \mathrm{~cm}$ long. Pre-limb lymph nodes (Inn. cervicales superficiales), $7-9 \mathrm{~cm}$ long.
Deep cervical lymph nodes (Inn. cervicales prof undi) - 0.3 $2 \mathrm{~cm}$ long. Ribal-cervical lymph nodes (Inn. costocervicales) $-1.5-3 \mathrm{~cm}$ long. Armpit lymph nodes (Inn. axillares proprea) - paired, $2.5-3.5 \mathrm{~cm}$ long. Patellar lymph nodes (Inn. subiliaci) $-6-11 \mathrm{~cm}$ long. Popliteal lymph nodes (Inn. poplitei), long $4.5 \mathrm{~cm}$. These lymph nodes are of great importance in the veterinary and sanitary examination of slaughter products.

Determination of pathological changes in organs and tissues. Abscesses, parasitic nodules, tumors, hemorrhages, dystrophies, and other pathological changes, as well as signs of sepsis of inflammatory foci, were not found. Appearance and color. The meat from the surface of the carcass had a dry crust of drying out. The color of the drying peel is pale pink, sometimes pale red. The surface of the fresh-cut is slightly moist but not sticky, bright red. Transparent meat juice. Consistency. On the cut, the meat is dense and elastic. The hole which is formed when pressing with a finger is quickly leveled.

Table 5 The maintenance of radionuclides in tests of meat.

\begin{tabular}{lccc}
\hline \multirow{2}{*}{ Inhabited point } & \multicolumn{2}{c}{ Specific activity of radionuclides, Bk/kg } \\
\cline { 2 - 4 } & Am-241 & Cs-137 & Pu-239/240 \\
\hline v. Bodene & $<0.5$ & $2.2 \pm 0.1$ & $0.056 \pm 0.001$ \\
v. Sarapan & $0.52 \pm 0.01$ & $3.1 \pm 0.2$ & $0.034 \pm 0.001$ \\
v. Sarzhal & $<0.3$ & $3.8 \pm 0.2$ & $<0.06$ \\
v. Dolon & $<0.5$ & $4.3 \pm 0.2$ & $<0.05$ \\
v. Mostik & $<0.2$ & $<1$ & $<0.02$ \\
v. Zhanan & $<0.2$ & $6.5 \pm 0.5$ & $<0.08$ \\
\hline
\end{tabular}


The carcasses received from the Sarzhal, Sarapan and Zanan wintering settlements showed the following indicators: The degree of bleeding is satisfactory. A small amount of blood was found in small blood vessels, there is no blood in the muscles, the cut surface is wet. The condition of the site of the cut. The location of the incision is uneven, soaked with blood. Determination of hypostases. There are no hypostases in the lower and upper parts of the carcass, that is, there are no blue-red areas soaked in blood. Definition of fatness carcasses. The presence of signs of exhaustion, emaciation is not observed, as well as signs of dystrophic and degenerative changes in the muscles were not found. The carcass is of medium fatness. State of lymph nodes. Parotid lymph node (Lymphonodus parotideus) $7-10 \mathrm{~cm}$ long. Submandibular lymph node (Lymphonodus submaxillaris) $3.5-5.0 \mathrm{~cm}$ long. Occipital lymph node (Lymphonodus retro pharyngeus medialis) $3.5-7 \mathrm{~cm}$ long. Winging lymph node (Lymphonodus pterygoideus) $0.75-1.5 \mathrm{~cm}$ long. Prescapular lymph nodes (Inn. cervicales superficiales), 8 - 12 $\mathrm{cm}$ long. Deep cervical lymph nodes (Inn. cervicales prof undi) $0.3-2 \mathrm{~cm}$ long. The rib-cervical lymph nodes (Inn. costocervicales) $1.5-3.5 \mathrm{~cm}$ long. Armpit lymphoid nodes (Inn. axillares proprea) $2.5-4 \mathrm{~cm}$ long. Patellar lymph nodes (Inn. subiliaci) $8-12 \mathrm{~cm}$ long. Popliteal lymph nodes (Inn. poplitei) $4.5-5.5 \mathrm{~cm}$.

Determination of pathological changes in organs and tissues: abscesses, parasitic nodules, tumors, hemorrhages, dystrophies, and other pathological changes, as well as signs of sepsis of inflammatory foci, was not found. Appearance and color: the meat from the surface of the carcass had a dry crust of drying out. The color of the drying crust is pale red. The surface of the fresh-cut is slightly wet but not sticky, red. Transparent meat juice. Consistency: On the cut, the meat is firm and elastic. The hole which is formed when pressing with a finger is leveled within one minute.

Fat of cattle of yellow color. The consistency is less firm, it does not crumble when pressed. There is no smell of rancid and salinization. Acid number -2.5 . The peroxide value of fresh fat was 0.05 . Bone marrow: fill the entire cavity of the tubular bone, elastic, yellow. At the break is brilliant, does not lag behind the edges of the bone. Tendons and joints: the tendon is elastic and dense, the articular surfaces are smooth and shiny. Synovial fluid in the joints is transparent. Broth when cooking meat: broth when cooking muddy with flakes, fragrant, fat with a fragrant smell. On the surface, there are not large droplets of fat. The taste of fat is normal.

Radiometric control showed that in all the test points understudy, the EDR values, the beta-particles flux density is below the limit of acceptable values. The EDR level is from $0.05 \mu \mathrm{Sv} / \mathrm{h}$ to $0.35 \mu \mathrm{Sv} / \mathrm{h}$. The measured values of the betaparticles flux density in all test points were $<10$ parts $/ \mathrm{min} \times \mathrm{cm}^{2}$.
As a result of alpha and gamma spectral analyzes, radionuclides Am-241, Cs-137 and $\mathrm{Pu}-239 / 240$ were detected in samples of soil, water from plants, meat and milk from the PRR. The specific activity of radionuclides in soils is Am-241, Cs-137 and Pu-239/240. A specific activity of radionuclides in soils make Am-241 from $0.3 \pm 0.1$ to $91.5 \pm 1.8 \mathrm{Bk} / \mathrm{kg}$, Cs$1370.5 \pm 0.1$ to $3658.6 \pm 22.5 \mathrm{Bk} / \mathrm{kg}, \mathrm{Pu}-239 / 240$ from 0.005 to $11.4 \pm 0.3 \mathrm{Bk} / \mathrm{kg}$; plants from Am-241 form 0.03 to $25.8 \pm 0.2$ $\mathrm{Bk} / \mathrm{kg}, \mathrm{Cs}-137$ from 0.2 to $1150.3 \pm 10 \mathrm{Bk} / \mathrm{kg}, \mathrm{Pu}-239 / 240$ from 0.0005 to $2.2 \pm 0.2 \mathrm{Bk} / \mathrm{kg}$; in the water $\mathrm{Am}-241$ from 0.002 to $0.15 \mathrm{Bk} / 1, \mathrm{Cs}-137$ from 0.01 to $2.5 \pm 0.1 \mathrm{Bk} / 1, \mathrm{Pu}-$ 239/240 from 0.0002 to $0.05 \mathrm{Bk} / \mathrm{l}$; in the meat Am-241 from 0.002 to $0.52 \pm 0.01 \mathrm{Bk} / \mathrm{kg}$, Cs-137 from 0.2 to $6.5 \pm 0.5 \mathrm{Bk} / \mathrm{kg}$, $\mathrm{Pu}-239 / 240$ from 0.0002 to $0.8 \mathrm{Bk} / \mathrm{kg}$; in the milk Am-241 from 0.013 to $2.3 \pm 0.2 \mathrm{Bk} / 1$, Cs- 137 from 0.1 to $12.3 \pm 0.3 \mathrm{Bk} / 1$, $\mathrm{Pu}-239 / 240$ from 0.0001 to $0.062 \pm 0.01 \mathrm{Bk} / \mathrm{l}$.

\section{Conclusions}

Current investigation shows that the migration of radionuclides in the soil-plant-animal-animal-livestock products chain depends on the soil and climatic conditions, changes in the physiological properties of plants and the physicochemical properties of radionuclides. The greatest migration ability of radionuclides was in the soil studied in populated areas Zhanan and Sarapan. Organoleptic assessment of the quality of cattle meat, under the conditions of the former SNT, revealed some discrepancies. In the carcasses obtained from the Sarzhal, Sarapan and Zanan wintering areas, the following indicators were noted: a slight increase in lymph nodes, muddy broth, the moisture content of the surface of muscle tissue.

\section{Conflict of Interest}

The authors declare no conflict of interest.

\section{References}

Amirbekov ShA, Dyusembaev ST, Amirkhanov KZh, Kakimov AK, Yessimbekov ZhS (2013) Current radioecological situation in the territories adjacent to the NPS. Dissertation, Scientific Center for Radioecological Research.

Apsalikov KN, Lipikhina A, Grosche B, Belikhina T(2019) The state scientific automated medical registry, Kazakhstan: an important resource for low-dose radiation health research. Biophysik. doi: 10.1007/s00411-018-0762-5.

Balmukhanov SB, Abdrakhmanov JN, Balmukhanov TS, Gusev BI, Kurakina NN, Raisov TG (2006) Medical effects and dosimetric data from nuclear tests at the Semipalatinsk test site. The technical report, Defense Threat Reduction Agency.

Dyussembaev ST, Serikova AT, Iminova DE (2013) Guidelines for radiological monitoring, veterinary and sanitary examination of animal products and radiation dose load on farm animals. Intellect publishing house, Semey. 
Gorlachev I, Kharkin P, Dyussembayeva M, Lukashenko S, Gluchshenko G, Matiyenko L, Zheltov D, Kitamura A, Khlebnikov N (2019) Comparative analysis of water contamination of the Shagan river at the Semipalatinsk test site with heavy metals and artificial radionuclides. Journal of Environmental Radioactivity. doi: 10.1016/j.jenvrad.2019.106110.

Gudkov IN (1991) Fundamentals of general and agricultural radiobiology: Studies aor universities. USKhA, Kiev.

Karabalin BK, Mukusheva MK, Kayrambayev SK (2001) Assessment of an average annual efficient dose of internal radiation of the population of the region of Semipalatinsk proving ground. NNC Bulletin 3:79-84.

Kudryavtsev VN (1991) Migration of Cs-137 in the food chain of cattle and the regulation of the receipt of the radionuclide in its links. Dissertation. Research Institute of Agricultural Radiology.

Larionova NV, Lukashenko SN, Kunduzbaeva AE, Ivanova AR, Keller SA (2011) Features of the transition of artificial radionuclides from soil to plants of steppe ecosystems at the site "Experimental field" of the former SIP. Actual Issues of Radioecology of Kazakhstan 3:85-99.

Law of the Republic of Kazakhstan of December 18, 1992 N 1787XII. About social protection of the citizens who injured owing to nuclear tests at Semipalatinsk proving nuclear test site. https://online.zakon.kz/document/?doc id=1001550\#pos=31;-155.

Lukashenko SN (2008) Complex studying of migration of radionuclides in the soil, water, plants, animals and influence of small chronic doses of radiation on biological objects in places of water manifestations of adits of the massif. The closing report, Institute of radiation safety and ecology of SENTS RK.
Panitskiy AV, Lukashenko SN, Batyrbekov EG, Berezin SA, Umarov MA, Strilchuk YuG, Yakovlev VV (2019) Practical experience in applying remediation methods at the Semipalatinsk test site (Kazakhstan). In: Gupta D, Voronina A (eds) Remediation Measures for Radioactively Contaminated Areas. Cham, Springer.

International Atomic Energy Agency (1998) Radiological conditions at the Semipalatinsk test site, Kazakhstan: preliminary assessment and recommendations for further study. IAEA, Vienna.

Rikhvanov LP (2009) Radioelements in a surrounding medium and radioecology problems. STT, Tomsk.

Semenova Y, Pivina L, Belikhina T, Manatova A, Bulegenov T, Zhuanyshev T (2018) Food safety practices in the territories adjacent to the former Semipalatinsk Nuclear Test. European Journal of Public Health. doi:10.1093/eurpub/cky213.515

Semenova Y, Pivina L, Manatova A, Bjørklund G, Glushkova N, Belikhina T, Dauletyarova M, Zhunussova T (2019) Mental distress in the rural Kazakhstani population exposed and non-exposed to radiation from the Semipalatinsk nuclear test site. Journal of Environmental Radioactivity 203:39-47.

Spiridonov C, Mukusheva MK, Choubina OA, Solomatin VM, Yepifanov IE (2008) Assessment of population exposure doses as a result of a radio contamination of the territory of Semipalatinsk proving ground Radiation Biology Radioecology 48:218-224. 